\title{
A stable haemagglutinating antigen for detecting toxoplasma antibodies
}

\author{
H. THORBURN AND H. WILLIAMS \\ From the Microbiology Laboratory, Raigmore Hospital, Inverness
}

SYNOPSIS The production of a toxoplasma-sensitized cell preparation stable for at least one yea at $5^{\circ} \mathrm{C}$ and its performance in the diagnosis of toxoplasmosis is described.

Although the decade 1960-1970 saw considerable and important developments in the biological and immunological aspects of toxoplasmosis, the diagnosis of the condition still presents considerable difficulties. When it is not possible to isolate the parasite, diagnosis is dependent largely on serological tests, and the dye test (Sabin and Feldman, 1948), or one of its modifications, is still the one which commands most confidence. However, the disadvantages associated with this test need no elaboration, especially the continuing need for live parasites and for accessory factor in addition to the heavy demands it makes on laboratory time. These factors have been instrumental in favouring the centralization of tests in a few specialized laboratories which perhaps to some extent acts as a limiting factor on the numbers of tests performed. Of all the possible substitutes for the dye test, haemagglutination (Jacobs and Lunde, 1957), direct agglutination (Fulton and Turk, 1959), fluorescent antibody methods (Goldman, 1957), and complement fixation (Fulton and Fulton, 1965), the haemagglutination test has many attractions, not only because of its sensitivity but because this kind of test can now be carried out in plastic plates in micro quantities enabling many sera to be tested readily.

In 1960 Mitchell and Green stated: 'If stable antigens can be prepared and distributed the (haemagglutination) test should lend itself to greater standardization than is possible with the dye test and warrants further investigation'. Some progress towards this goal was made by Maloney and Kaufman (1960) and Park (1961) by the use of formolized cells and by Jennis (1966) using pyruvic aldehydetreated cells. However, all of these cell preparations had a relatively short life at $5^{\circ} \mathrm{C}$.

Received for publication 16 June 1972.
The sensitized cell preparation we describe hereo is stable for at least one year at $5^{\circ} \mathrm{C}$ and in our hands has proved a useful and reliable tool in the $e_{s}$ diagnosis of toxoplasmosis.

\section{Material and Methods}

\section{CELLS}

Sheep erythrocytes, obtained at the abattoir, we्ge collected in Alsever's solution, stored at $5^{\circ} \mathrm{C}$ a used within a fortnight of collection. The treatmento of the cells with pyruvic aldehyde ${ }^{1}$ followed essentially the method described by Jennis and these treated cells were stored at $5^{\circ} \mathrm{C}$ in Sorenson's phosphate- $\frac{0}{8}$ buffered saline, $p H \quad 7 \cdot 2$, containing $0.1 \%$ sodium azide. Cells prepared in this fashion may be stored $\overrightarrow{\vec{\partial}}$ without deterioration and are available for sensitiz- $\exists$ ation as and when required.

\section{ANTIGEN}

Cotton rats, 12-15 weeks old, were inoculated intraperitoneally with the RH strain of toxoplasma and 66 to 68 hours later the peritoneal exudate was harvested in saline. Such exudates were rich in parasites with very few white cells; any very rare 0 blood-tinged or cellular exudates were discarded. The exudate was washed once in saline and 1 part of the deposit was mixed with 9 parts of distilled water and frozen and thawed three times. After minimal $\sim$ centrifuging to remove gross particles, the super- $N$ natant constituted the sensitizing antigen which was stored at $-20^{\circ} \mathrm{C}$.

\section{CELL SENSITIZATION}

Pyruvic aldehyde-treated cells were thrice-washed in $\mathscr{Ð}$ saline and resuspended in Sorenson's buffered

'Pyruvic aldehyde (40\% aqueous solution) obtained from Messrs Kodak, Ltd, Kirby, Liverpool. 
saline $p H$ 6.0. The packed cell volume was obtained from a haematocrit tube estimation and the cell concentration adjusted to $1.4 \%$ with the $p \mathrm{H} 6.0$ buffer. Antigen was also diluted in this buffer to the required concentration as determined by previous chessboard titration against the WHO Toxoplasma Reference Serum. The antigen standard employed was the highest dilution, usually $1: 200$ to $1: 500$, producing a haemagglutinating antibody titre of 1:1000 with the reference serum.

The diluted antigen was mixed with an equal volume of the $1.4 \%$ cell suspension and sensitization proceeded for one hour in a water bath at $56^{\circ} \mathrm{C}$. (It was found to be important in producing batches of cells comparable in sensitivity to that of the initial titration to sensitize cells in small volumes. Thus if each tube of an antigen titration was of a $10 \mathrm{ml}$ cell/antigen volume then larger volumes were sensitized in approximately $10 \mathrm{ml}$ amounts.) On removal from the water bath, the coated cells were cooled under running tap water, washed once in saline and resuspended to an $0.7 \%$ concentration in Sorenson's phosphate-buffered saline, $p \mathbf{H} 7 \cdot 2$, containing $0.1 \%$ sodium azide. Storage was at $5^{\circ} \mathrm{C}$.

TESTING OF SERUM SPECIMENS FOR ANTIBODY Haemagglutination (HA) tests were all carried out using the Microtiter ${ }^{2}$ apparatus in permanent lucite V-welled plates with a standard volume of $0.05 \mathrm{ml}$. Doubling dilutions of the test serum were made in $2 \%$ serum saline (diluent serum was either foetal bovine serum or human toxoplasma antibody-free serum). Of the well mixed sensitized cells, $0.05 \mathrm{ml}$ was added to each well, the plate tapped to mix, and left undisturbed on the bench at room temperature. Cell and antibody controls were included in each test. Results were read after leaving overnight at room temperature but in fact a two-hour reading was equally satisfactory.

Dye tests were performed in this laboratory by the method used in the PHLS Toxoplasma Reference Laboratory, Leeds, but with parasites harvested from the peritoneal exudate of infected cotton rats instead of mice.

Ultracentrifugation of sera was carried out on sucrose density gradients formed from 10 to $50 \%$ sucrose concentrations in an MSE Superspeed 50 at $40000 \mathrm{rpm}$ for 18 hours.

Titres obtained using sensitized cells were compared with dye test titres on the sera of patients grouped as follows:

(1) Twenty-two sera received from Dr G. B. Ludlam of the Toxoplasma Reference Laboratory, Leeds, where a diagnosis of acquired toxoplasmosis

Coske Engincering Co. was based on clinical findings substantiated by significant dye test titres.

(2) Eighty-four sera from patients attending ophthalmic clinics where choroiditis was detected and where the ophthalmologist considered the diagnosis of toxoplasmosis likely or possible on clinical grounds.

(3) A group of 161 sera from cases of lymphadenopathy including patients with the glandular fever syndrome, rheumatoid arthritis, and others in a miscellaneous group where the diagnosis of toxoplasmosis was considered a possibility by the clinician concerned and who submitted the serum for toxoplasma antibody examination.

(4) One hundred and twenty-four embryopathy sera from babies in the Western Region of Scotland including two cases of congenital toxoplasmosis diagnosed on clinical and laboratory evidence (Ross et al, 1972).

(5) A group of 459 sera from pregnant women from the north of Scotland who were attending routine surveillance clinics.

\section{Results}

In group 1 (Fig. 1), in general a high titre group, 20 of the 22 sera gave readings which were either the same or within a single dilution reading between the

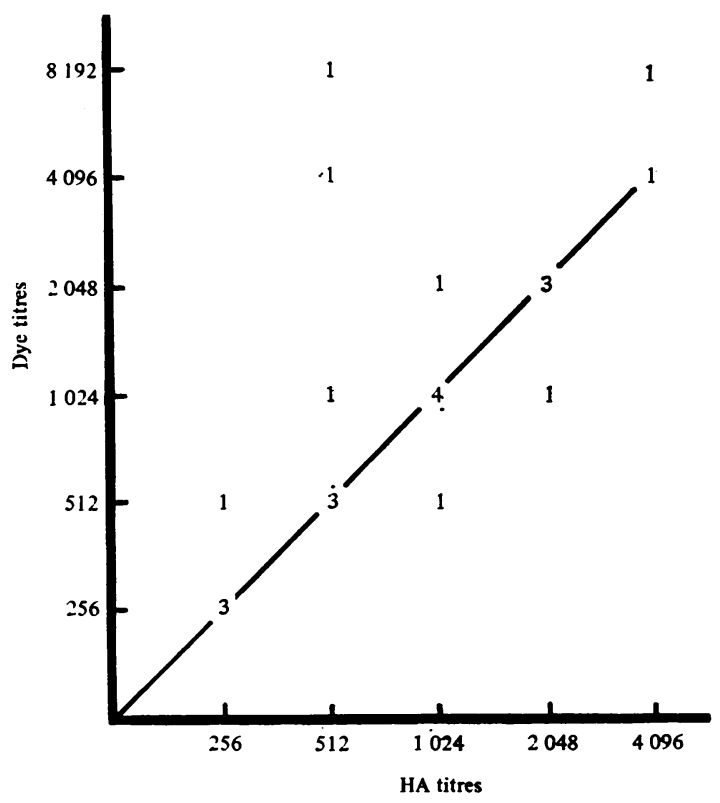

Fig. 1 Haemagglutination and dye test titres of 22 cases of acquired toxoplasmosis (group 1). 


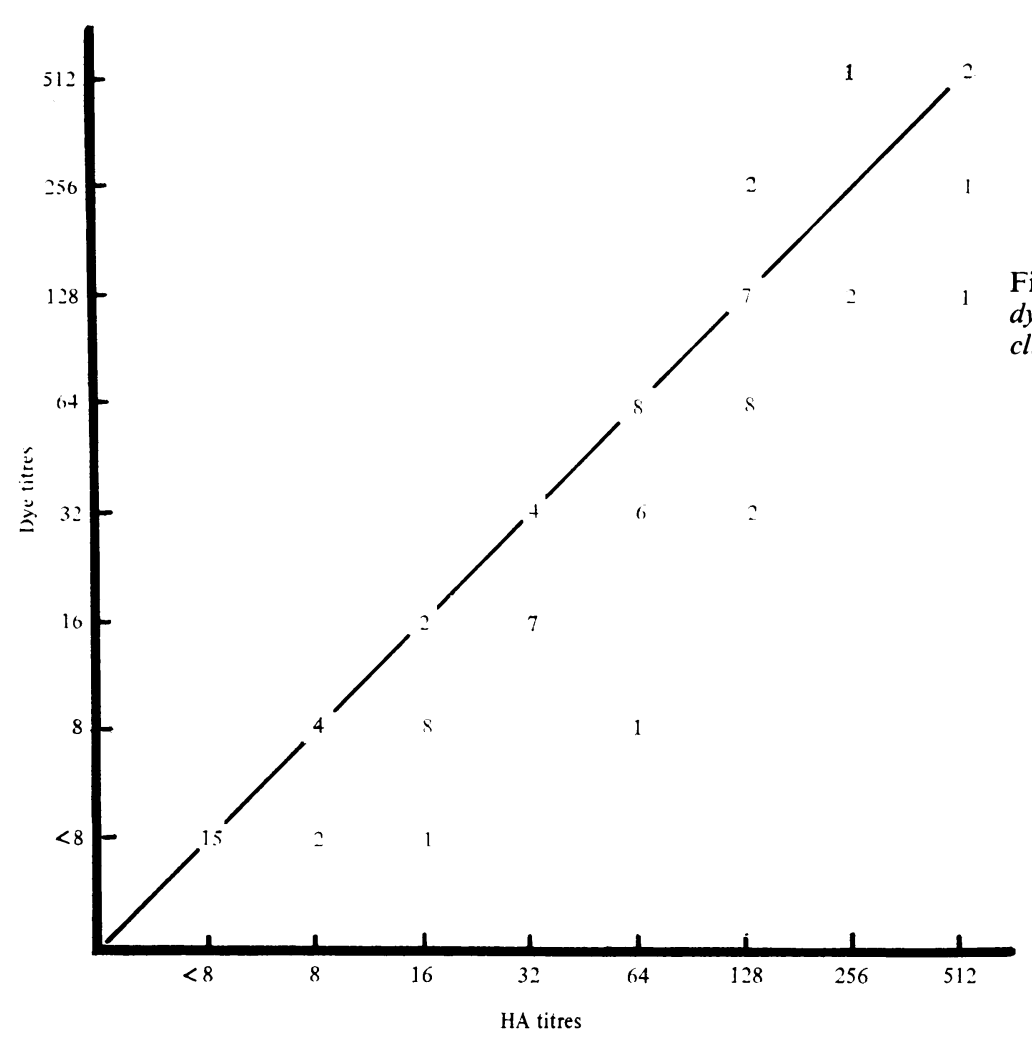

Fig. 2 Haemagglutination and dye test titres of 84 ophthalmic clinic sera (group 2).

two tests. In the two sera where the difference was greater, the dye test showed respectively an eight-fold and a 16-fold increase over the HA titre of 1:512.

In group 2 , the agreement between the dye and HA titres was very close, only one serum of the 84 submitted showing a difference more than four-fold, as shown in Figure 2.

Group 3 is a heterogeneous group of sera and includes serum from cases with the glandular fever syndrome as well as cases of rheumatoid arthritis. In this group of 161 sera, of which 16 were positive by the Paul-Bunnell test and 17 by the Rose-Waaler test, 127 showed agreement between the toxoplasma dye and HA tests within fourfold limits. Positive Paul-Bunnell sera were easily identified by their agglutination of pyruvic aldehyde-treated but nonsensitized sheep cells. Since sheep cell agglutinins are not readily completely removed from high titre Paul-Bunnell-positive sera it is easier to identify them thus than to attempt absorption in routine practice.

One hundred and twenty-four embryopathy sera, all gathered in the neonatal period and earlier tested against a variety of viral antigens, made up group 4 .
The two sera shown in Fig. 4, where both HA and dyê test titres were in excess of $1: 256$, gave final titres o $\overrightarrow{\vec{b}}$ 1:1024 and 1:4096. The respective dye test titres were $1: 512$ and 1:8192. Thirty sera, however, had comparatively high HA titres $(\geqslant 1: 32)$ in the. absence of correspondingly high dye test titres.

Four hundred and twenty-one of the 459 sera is this group (group 5) agreed within four-fold limits Of the 38 sera outside those limits the preponderanc8 was entirely towards higher HA readings. The behaviour of the HA and dye test antigens was followed through in serial serum samples from on antenatal patient where rising dye test titres suggestect active infection. The samples from mother and baby. were fractionated on sucrose density gradients and the results are shown in Figure 6.

\section{Discussion}

Using freshly sensitized cells, Jacobs and Lunde originally found that $93 \%$ of their sera tested bye both HA and dye test had titres which agreed within a four-fold difference while $4 \%$ showed 5 differences greater than 16-fold. The stable HAP 


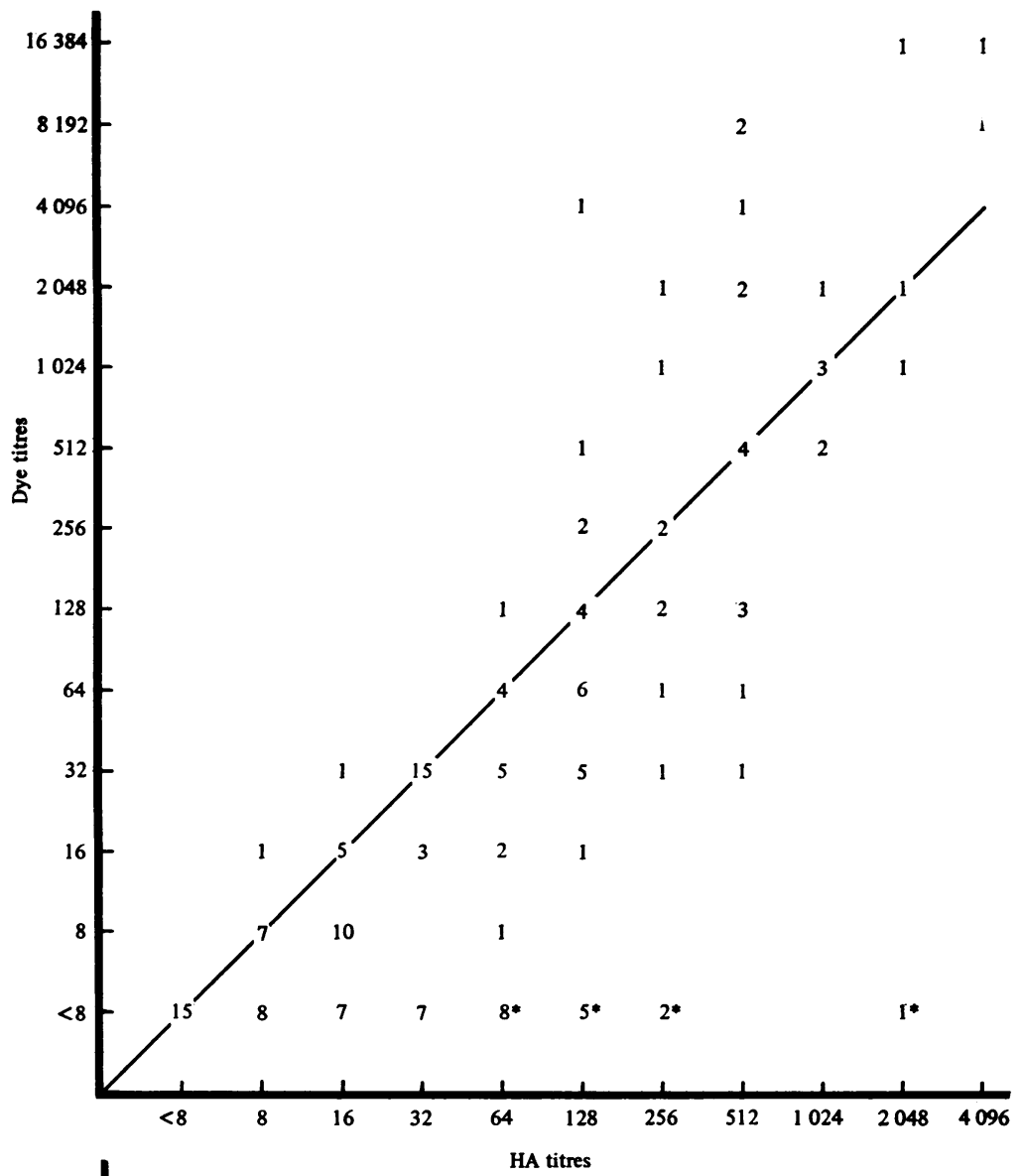

Fig. 3 Haemagglutination and dye test titres of 161 sera including cases of lymphadenopathy, glandular fever and rheumatoid arthritis (group 3). $\mathrm{X}=$ Positive Paul-Bunnell test sera.

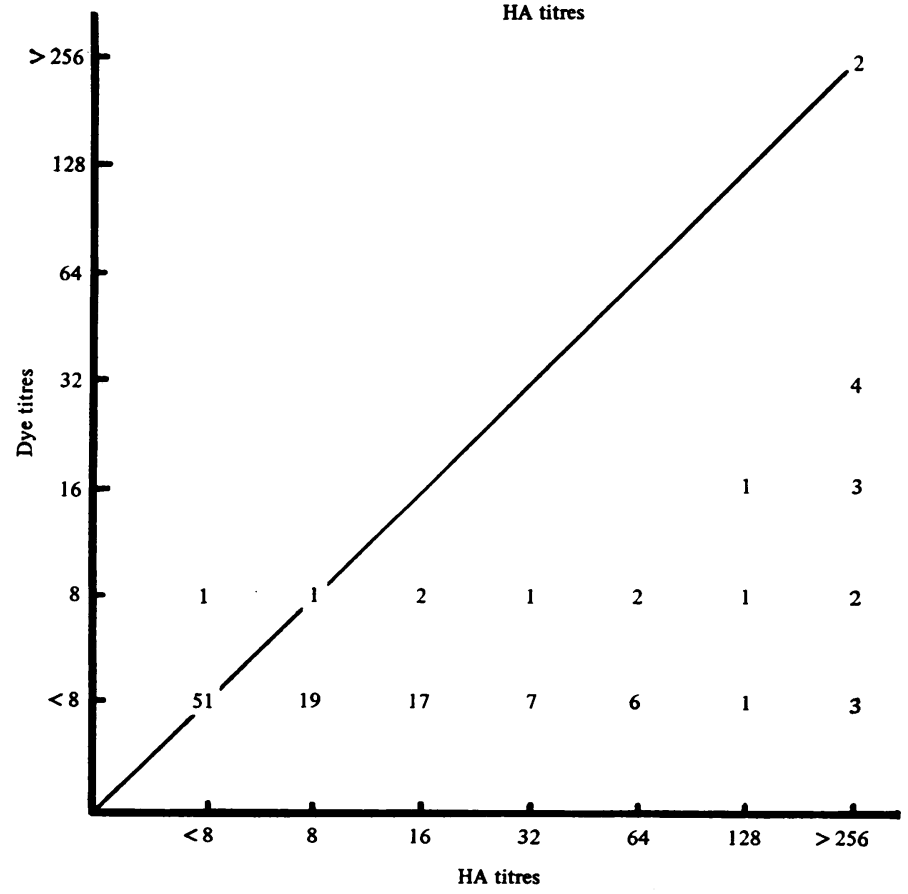

Fig. 4 Haemagglutination and dye test titres of 124 embryopathy sera (group 4). 


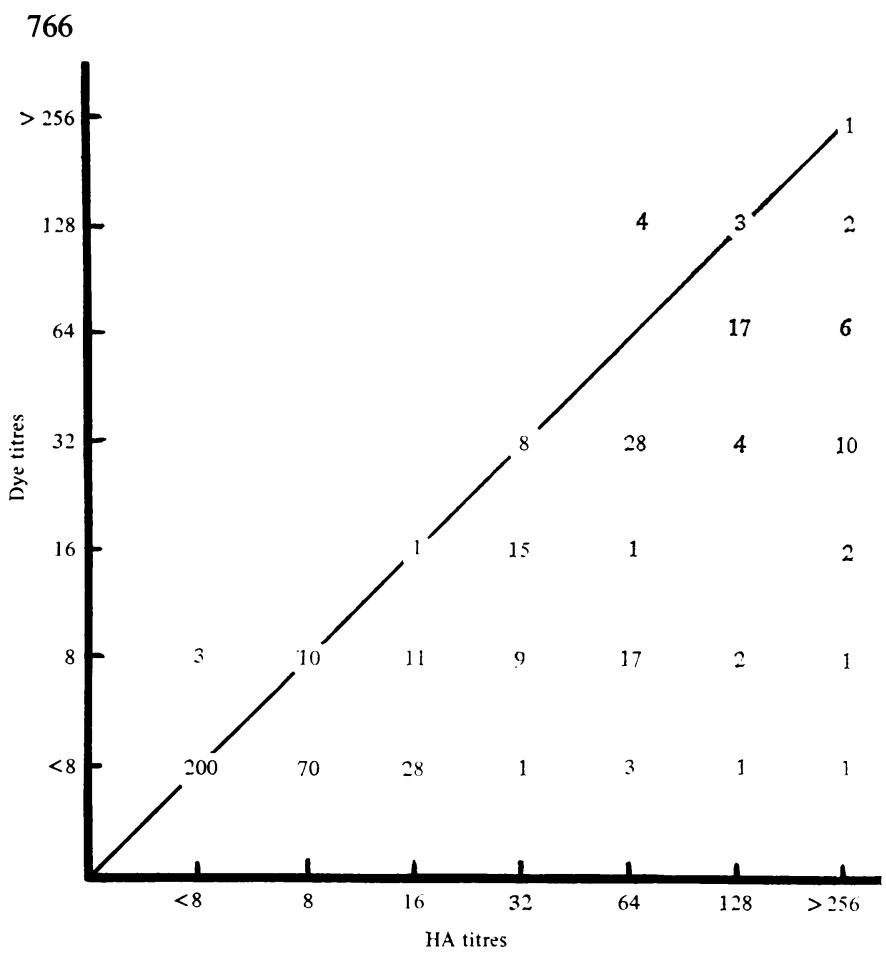

Fig. 5 Haemagglutination and dye test titres of 459 antenatal clinic sera (group 5).
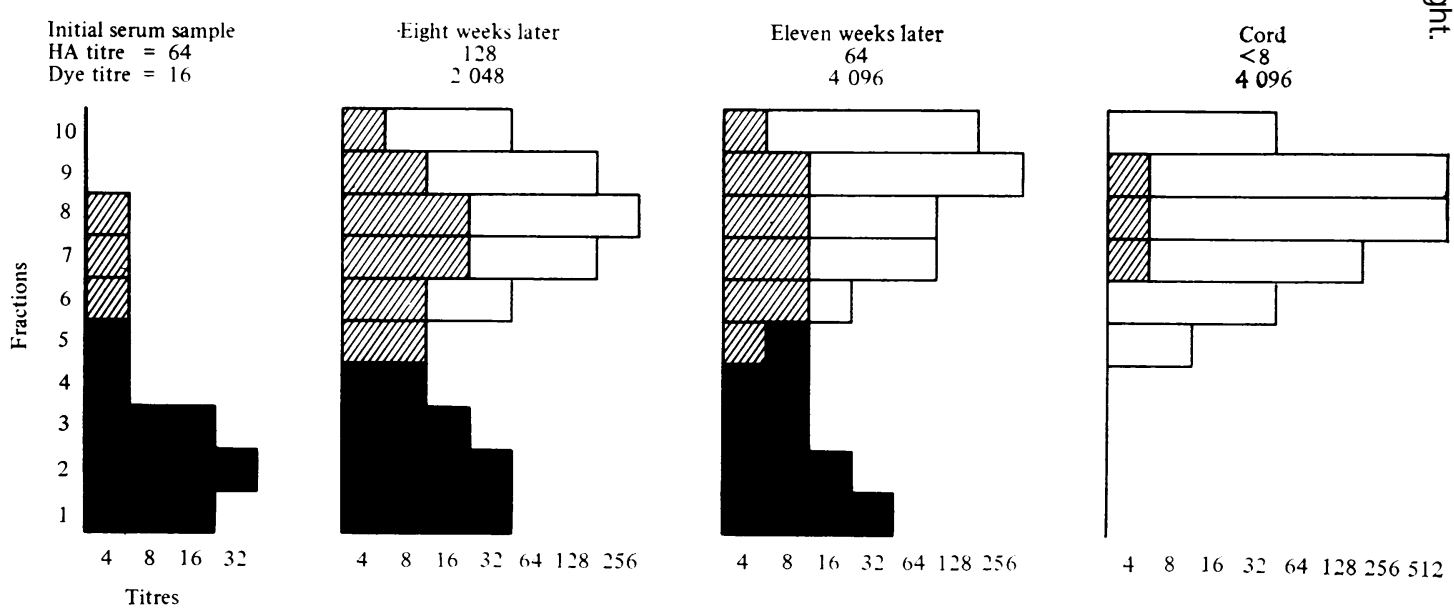

Fig. 6 Haemagglutination and dye test results of testing sucrose density gradient ultracentrifugation fractions of serial samples of serum and cord blood from antenatal patient of group 5. (Fractions 1 to 3 are IgM; fractions 5 to 10 are IgG.) $\quad$ = Haemagglutination titre $\square=$ dye titre $\mathbb{Q}=$ haemagglutination and dye titres?

antigen, standardized against the WHO reference serum and tested on the 850 sera comprising groups $1-5$, was found to agree, within four-fold limits, with the dye test titre in $745(88 \%)$ of the sera; 105 sera
$(12 \%)$ had greater than four-fold differences between the two tests. However, the correlation of titres. varied widely according to the particular group beingexamined. 
Ninety-one per cent of the sera in group 1 were either the same, or within a single dilution difference in both tests, and in the ocular cases in group 2 agreement within a four-fold limit was as high as $99 \%$.

Group 3 included positive Paul-Bunnell and also positive Rose-Waaler test sera. Although the difficulty of Paul-Bunnell sera could have been overcome by the use of sensitized human, rather than sensitized sheep, cells the best correlation between HA and dye test titres has been found by those workers employing sheep cells (Chordi et al, 1964). The three highest Rose-Waaler titre (1:256) sera had neither toxoplasma HA nor dye test antibodies; conversely one of the lowest Rose-Waaler (1:32) sera had a toxoplasma HA and dye test titre of 1:256.

Within the four-fold criterion the agreement with HA and dye titres in group 3 was $79 \%$ but if the 16 Paul-Bunnell-positive sera are omitted the level of agreement is increased to $88 \%$.

The 124 embryopathy sera in group 4 showed the poorest correlation of $\mathrm{HA}$ and dye test titres, $24 \%$ of the sera tested had positive HA titres at least four-fold higher than the respective dye titres. However, the two highest titred sera were from cases diagnosed on clinical grounds as congenital toxoplasmosis.

Group 5 showed a $92 \%$ agreement of HA and dye test titres within the four-fold limit. When a second specimen obtained from one of the patients in this group showed a raised dye titre a further specimen of blood and also cord blood was obtained at delivery. The HA and dye results of fractions separated in sucrose density gradients by ultracentrifugation were of value in demonstrating the sensitivities of the two tests.

Whilst there is evidence that the dye test and HA tcst measure different antibodies (Fleck, 1961) we have not found a positive dye test in the absence of HA antibody in any of the acute human sera nor in sera from many experimental animals which we have infected. As in the acute form of the acquired disease and in the congenital form the early antibody is of $\operatorname{IgM}$ nature (Remington, 1968), the HA test is particularly useful in these cases because of the relatively greater haemagglutinating efficiency of IgM antibody as opposed to antibody of the IgG class which appears to be more sensitively measured by the dye test
(Fig. 6). If this is so the correlation of $\mathrm{HA}$ and dye results may rest to some extent on the relative concentrations of the immunoglobulin class of toxoplasma antibody present in the serum.

In the entire series of 850 sera, no serum was found with an HA titre of 1:32 which had a dye test titre greater than this.

We believe that the employment of this reagent would enable laboratories to undertake a wider screening of sera than would be practical if all sera had to be submitted to the dye test.

We wish to thank Dr G. B. Ludlam for the hospitality of his laboratory in which one of us (H.T.) worked, and for his advice.

This work has been supported by a grant from the Scottish Hospital Endowments Research Trust.

\section{References}

Chordi, A., Walls, K. W., and Kagan, I. G. (1964). Studies on the specificity of the indirect hemagglutination test for toxoplasmosis. J. Immunol., 93, 1024-1033.

Fleck, D. G. (1961). Serological tests for toxoplasmosis. Nature (Lond.), 190, 1018-1019.

Fulton, J. D., and Fulton, F. (1965). Complement fixation tests in toxoplasmosis with purified antigen. Nature (Lond.), 205, 776-778.

Fulton, J. D., and Turk, J. L. (1959). Direct agglutination test for toxoplasmosis. Lancet, 2, 1068-1069.

Goldman, M. (1957). Staining Toxoplasma gondii fluorescein with labelled antibody II. A new serologic test for antibodies to toxoplasma based upon inhibition of specific staining. $J$. exp. Med., 105, 557-573.

Grey, H. M. (1964). Studies on changes in the quality of rabbit-bovine serum albumin antibody following immunization. Immunology, 7, 82-90.

Jacobs, L., and Lunde, M. N. (1957). A hemagglutination test for toxoplasmosis. J. Parasit., 43, 308-314.

Jennis, F. (1966). A simplified haemagglutination test for toxoplasmosis using pyruvic aldehyde treated cells. Aust. J. exp. Biol. med. Sci., 44, 317-322.

Maloney, E. D., and Kaufman, H. E. (1960). The rapid and convenient detection of toxoplasma antibodies using formaldehydetreated human erythrocytes. Amer. J. Ophthal., 50, 945-950.

Mitchell, R. G., and Green, C. A. (1960). The haemagglutination test for toxoplasma antibodies. J. clin. Path., 13, 331-335.

Park, H. K. (1961). Toxoplasma hemagglutination test, using alcoholformalin fixed sensitized lyophilized erythrocytes. Arch. Ophthal., 65, 184-191.

Remington, J. S., Miller, M. J., and Brownlee, I. (1968). IgM antibodies in acute toxoplasmosis. II. Prevalence and significance in acquired cases. J. Lab. clin. Mid. , 71, 855-866.

Ross, C. A. C., Bell, E. J., Kerr, M., and Williams, K. A. B. (1972). Infective Agents and Embryopathy in the West of Scotland, 1966-70. In press.

Sabin, A. B., and Feldman, H. A. (1948). Dyes as microchemical indicators of a new immunity phenomenon affecting a protozoon parasite (Toxoplasma). Science, 108, 660-663.

Siim, J. C., and Lind, K. (1960). A toxoplasma flocculation test. Acta path. microbiol scand., 50, 445-446. 